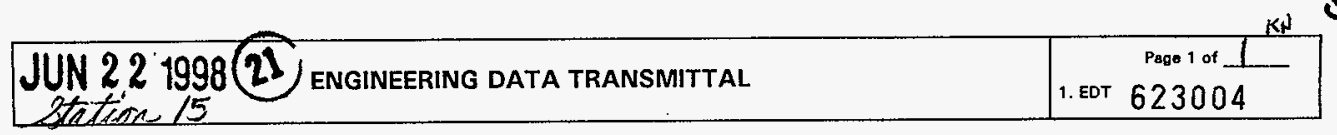

2. To: (Receiving Organization) 3. From: (originating organization)

4. Related EDT No.:

$\mathrm{NA}$

BWH Hanford Company Maste

5. Proj./Prog./Dept./Div.:

6. Design Authority/ Design Agent/Cog.

HAN73100

7. Purchase order No.:

Harvey J. Goldberg

8. Originator Remarks:

Approval/Release

11. Receiver Renarks:

11A. Design Baseline Document? [X] Yes

[] No

NA

9. Equip./Component No.:

NA

10. System/Bldg./Facility: WRAP

12. Major Assm. Dwg. No.:

NA

13. Permit/Permit Application No.: NA

14. Required Response Date:

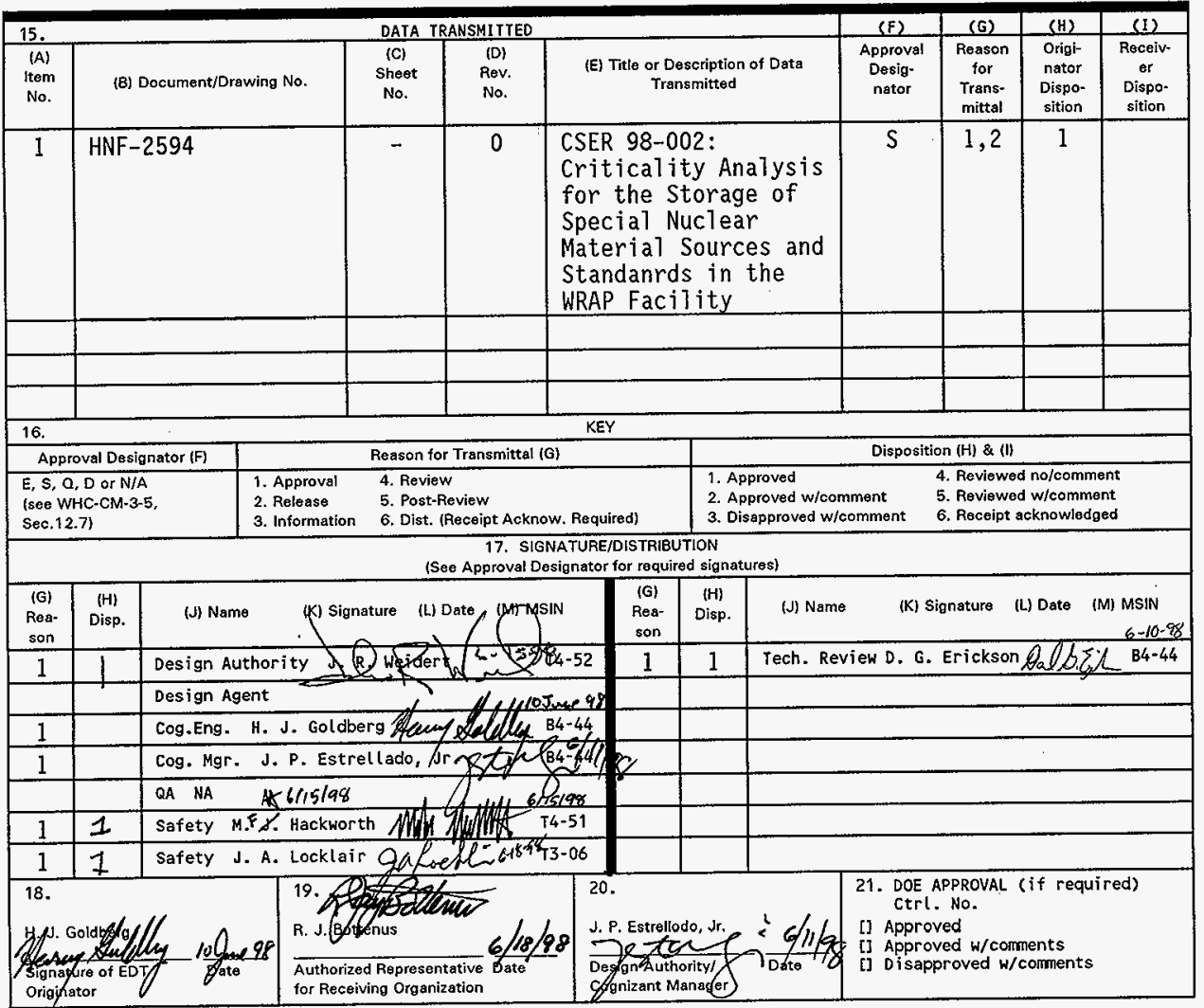




\section{CSER-98-002: CRITICALITY ANALYSIS FOR THE STORAGE OF SPECIAL NUCLEAR MATERIAL SOURCES AND STANDARDS IN THE WRAP FACILITY}

Harvey J. Goldberg

Fluor Daniel Northwest, Inc., Richland, WA 99352

U.S. Department of Energy Contract DE-AC06-96RL13200

EDT/ECN: $623004 \quad$ UC:

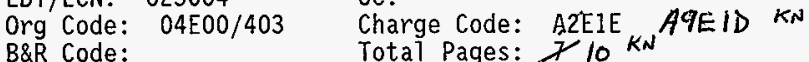

Key Words: Nondestructive assay, nondestructive examination, TRU, Sandards, Sealed Sources, Waste, Criticality

Abstract: The storage of test and calibration in order to ascertain potential for a criticality and develope criticality prevention limits.

TRADEMARK DISCLAIMER. Reference herein to any specific comercial product, process, or service by trade name, trademark, manufacturer, or otherwise, does not necessarily constitute or imply its endorsement, recommendation, or favoring by the United States Government or any agency thereof or its contractors or subcontractors.

Printed in the United States of America. To obtain copies of this document, contact: Document Control Services, P.0. Box 950, Mailstop H6-08, Richland WA 99352, Phone (509) 372-2420; Fax (509) 376-4989.
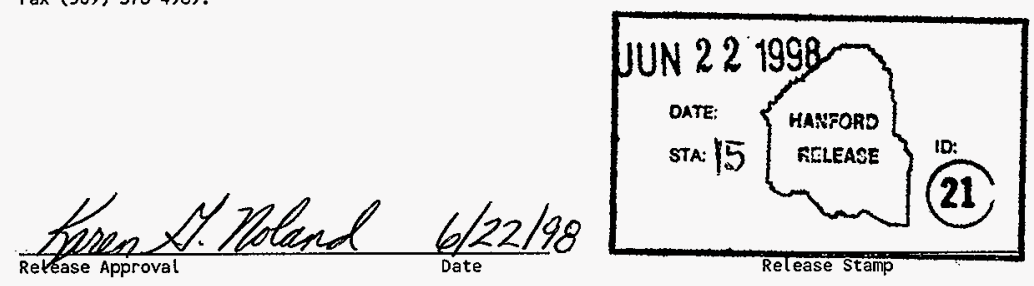
HNF-2594, Rev. O

CSER-98-002: Criticality Analysis for the Storage of Special Nuclear Material Sources and Standards in the WRAP Facility
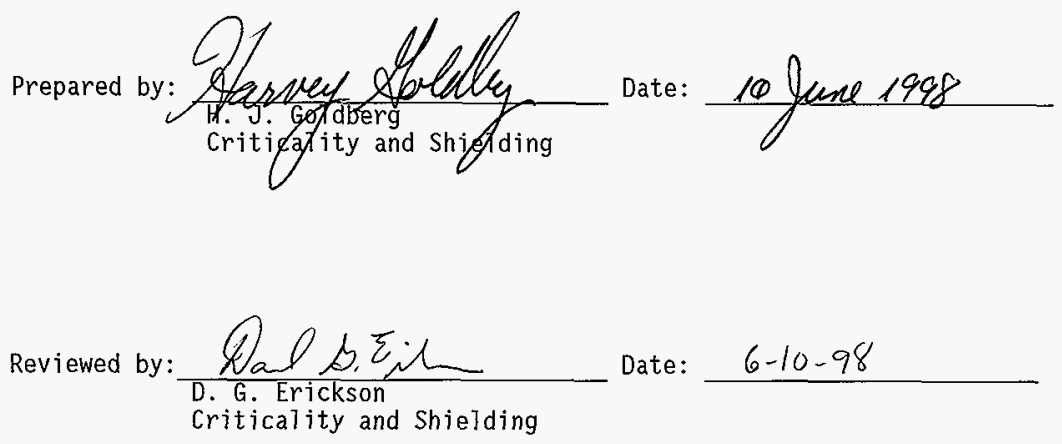

Approved by:
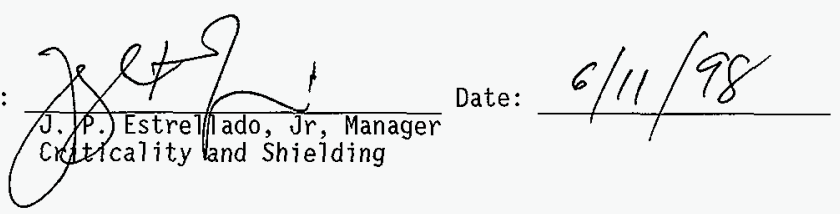


$$
\text { HNF-2594, Rev. } 0
$$

\section{TABLE OF CONTENTS}

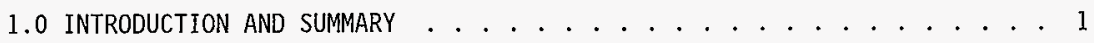
2.0 LIMITS . . . . . . . . . . . . . . . . . I

2.1 Pu Mass Equivalent Limits . . . . . . . . . . . . . 1

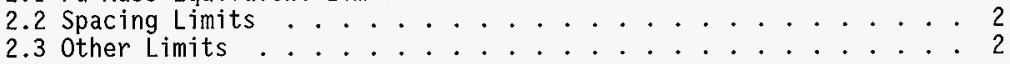
3.0 DESCRIPTION OF FACILITY . . . . . . . . . . . . . 3 4.0 EVALUATION OF CRITICALITY SAFETY CONTROLS . . . . . . . . . . 4 5.0 TECHNICAL PEER REVIEW . . . . . . . . . . . . . 6

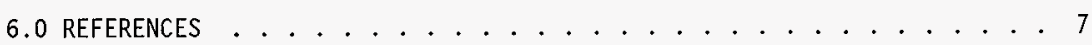


HNF-2594, Rev, $O$

\subsection{INTRODUCTION AND SUMMARY}

The Waste Receiving and Processing (WRAP) FaciTity will store uranium and transuranic (TRU) sources and standards for certification that WRAP meets the requirements of the Quality Assurance Program Plan (QAPP) for the Waste Isolation Pilot Plant (WIPP). In addition, WRAP must meet internal requirements for testing and validation of measuring instruments for nondestructive assay (NDA).

In order to be certified for WIPP, WRAP will participate in the NDA Performance Demonstration Program (PDP). This program is a blind test of the NDA capabilities for TRU waste. It is intended to ensure that the NDA capabilities of this facility satisfy the requirements of the quality assurance program $\mathrm{pl}$ an for the WIPP. The PDP standards have been provided by the Los Alamos National Laboratory (LANL) for this program. These standards will be used in the WRAP facility.

To internally check the accuracy and sensitivity of the NDA instruments, a further set of sources and standards will also be used by the facility. Each sealed source or standard will be referred to herein as a unit. Various combinations of these units will be placed in test drums and/or boxes which will be subject to their own limits until unloaded. There will be two sealed test drums with five grams of weapons grade plutonium loaded in them. These drums will be appropriately marked and will be subject to the unit limits rather than the drum limits.

This analysis shows that the storage and use of special nuclear material sources and standards within the limited control facility of WRAP (Rooms 101 and 104) is safe from a criticality standpoint. With the form, geometry, and masses involved with this evaluation, a criticality is not possible. The limits given in Section 2 below should be imposed on facility operations.

\subsection{LIMITS}

\subsection{Pu Mass Equivalent Limits}

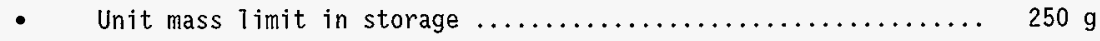

- Limit in test drum/box .................................. $475 \mathrm{~g}$

- Limit in storage room ..............................4 $4500 \mathrm{~g}$ 


$$
\text { HNF-2594, Rev O }
$$

\subsection{Spacing Limits}

- Between a unit mass and any other fissile material $\ldots \ldots \ldots \ldots 25 \mathrm{~cm}$

Exception: This spacing limit will not apply to the loading or unloading of test drums/boxes or the loading of unit masses into a glovebox. These operations will be limited by the drum/box limit (see below) or the glovebox limits, whichever is appropriate.

- Between any loaded test drum/box and any other loaded test drum/box or between any loaded test drum/box and any fissile mass, including those in gloveboxes ................... $92 \mathrm{~cm}$

Exception: This spacing 1 imit will not apply to loaded test drums to be used in the TRU glovebox. In those cases, all limits applicable to the glovebox will appiy to that drum.

Exception: Locked drums containing no more than six grams of weapons grade plutonium and clearly marked on the outside will be subject to the unit mass 1 imits (see above) rather than the drum limits.

\subsection{Other Limits}

- Only encapsulated (sealed) sources or standards will be allowed to be used in any test of the NDA equipment or stored in the source storage area.

- Stored unit masses on sheives will be constrained from falling by a positive constraint such as, but not limited to a latched bar across the entire shelf or a latched door across the front of a storage unit.

Exception: Stored unit masses on shelves will be unconstrained only during placing in or removal from storage of material.

- Storage containers with a maximum of $250 \mathrm{~g}$ of fissile material is allowed to be unconstrained at any time.

Exception: For purposes of loading unit masses into a test $\mathrm{drum} / \mathrm{box}$, a unit mass will be considered to be constrained if it is loaded into the test drum/box.

- $\quad$ Stored loaded PDP drums or boxes wil1 be constrained by a chain or strap attached to a stationary upright structure such as a wall, column, or chain link fence 
HNF-2594, Rev. O

\subsection{DESCRIPTION OF FACILITY}

The WRAP facility will store various sources and standards in the nuclear materials cage at the west end of Room 104. Within this room is the NDA equipment which these standards are intended to check and test.

There will be various sealed sources and standards producing neutrons by $(\alpha, n)$ reactions $\left({ }^{239} \mathrm{PuBe},{ }^{241} \mathrm{AmBe}\right)$ or by spontaneous fission $\left({ }^{239} \mathrm{Pu},{ }^{235} \mathrm{U},{ }^{241} \mathrm{Am}\right)$. These may contain up to $80 \mathrm{~g}$ of fissionable material and are sealed in stainless steel. These will be stored in slip-lid cans or similar containers which will themselves be stored, two in a drum, in 25, 30, or 55 gallon drums with the unoccupied space filled with paraffin. The drums will be stored with at least $25 \mathrm{~cm}$ between them, outside surface to outside surface. Sources wi11 also be stored on shelving either inside the nuclear materials cage or adjacent to this area.

The PDP sources will be $\mathrm{PuO}_{2}$ or $\mathrm{UO}_{2}$ encapsulated in stainless steel. The plutonium will be weapons grade and the uranium will be enriched in the isotope ${ }^{235} \mathrm{U}$ up to $94 \%$. Various numbers of these sources will be placed in steel cylinders, packed with either carbon felt material or diatomaceous earth. The source cylinders will be from 3.8 to $5 \mathrm{~cm}$ in diameter and from 5 to $24 \mathrm{~cm}$ in length. These cylinders will be welded shut containing from 300 $\mathrm{mg}$ to $100 \mathrm{~g}$ of plutonium or uranium.

The WRAP facility will have sources similar to the PDP sources (pseudoPDP sources) but ranging in size from $1 \mathrm{mg}$ to $50 \mathrm{~g}$ of fissile material. The difference between these and the PDP sources is purely administrative. The pseudo-PDP sources will be owned and used by the facility while the PDP sources may be used by outside certifiers.

The PDP and pseudo-PDP sources will be stored on shelves or in 55-gallon drums, with proper spacing between unit masses. The PDP and pseudo-PDP storage drums will not be filled with paraffin, and the sources will not be first placed in slip-lid cans.

Test drums and/or boxes will be loaded uniquely each time they are used. The test drums will be $55 \mathrm{gal}$ drums ( ID $=57 \mathrm{~cm}$, Inside Height $=84.5 \mathrm{~cm}$, constructed of 16 gauge steel). It is planned that each drum will have no more than $350 \mathrm{~g}$ of fissile material in it when loaded. This material will be in the form of PDP or pseudo-PDP sources loaded into the drum for a specific test of the NDA equipment. The radial spacing of the sources within the drum will be maintained by their insertion into from 5 to 8 fixed vertical positioning tubes $(O D \leq 7.5 \mathrm{~cm}$, ID $\leq 7 \mathrm{~cm}$ ) that extend the length of the drum. Vertical spacing within these positioning tubes will be maintained by the use of spacers. The positioning tubes will be at least $8.5 \mathrm{~cm}$ apart, center-tocenter. 


$$
\text { HNF-2594, Rev. } 0
$$

There wi1l also be test boxes loaded similarly to the test drums. Two types of boxes are planned, the B-25 box and the SWB box. It is planned that these boxes have no more than $450 \mathrm{~g}$ of fissile material loaded into them. The B-25 box is $115.6 \mathrm{~cm}$ wide, $183 \mathrm{~cm}$ long, and $117 \mathrm{~cm}$ high (inside dimensions). Within the box are up to 20 vertical or horizontal positioning tubes $(6<O D<23 \mathrm{~cm})$ extending the height or length of the box. The tubes will be distributed across the volume of the box, at least $8.5 \mathrm{~cm}$ apart, center-tocenter.

The SWB box consists of two flat sides and two rounded sides. The box is $91.9 \mathrm{~cm}$ tal1 and $132 \mathrm{~cm}$ wide. The $\mathrm{flat}$ sides are $114 \mathrm{~cm}$ long with the curved ends giving the box a maximum length of $175 \mathrm{~cm}$. Within the box are up to 20 vertical or horizontal positioning tubes $(0 D=23 \mathrm{~cm})$ extending the height or length of the box. The tubes will be distributed across the volume of the box, at least $8.5 \mathrm{~cm}$ apart, center-to-center.

The test drums and/or boxes may be either empty or filled with a variety of matrix materials; plastic, paper, clothing, glass, scrap metal, vermiculite, wood shavings, sand, and/or solidified organic or inorganic material. In rare cases, PDP matrices may consist of combustible materials.

The test containers will be loaded before each test and unloaded afterwards. Thus, they will general1y be empty of fissile material. However, there may be more than one test drum and/or box loaded for any specific testing period. There will also be two test drums with five grams of weapons grade plutonium which will be continually loaded. These drums will be locked and clearly marked. For the purposes of this analysis, these drums will be treated as individual sources.

\subsection{EVALUATION OF CRITICALITY SAFETY CONTROLS}

Each of the TRU sources and standards are sealed in stainless steel. The PDP and pseudo-PDP sources are sealed inside a second stainless steel container. It is not considered credible that a significant amount of plutonium or uranium or plutonium could be saturated with water. At worst, each source may be fully reflected by being immersed in water.

ARHCO, 1968 presents minimum critical configurations with respect to a variety of parameters. Graph III.A.9(100)-5 illustrates the behavior of a sphere of ${ }^{239} \mathrm{PuO}_{2}\left(\mathrm{H} / \mathrm{Pu}_{3}=0\right)$ fully reflected by water. At the theoretical density $\left(\rho=10.11 \mathrm{~g} / \mathrm{cm}^{3}\right)$, it would take $10.11 \mathrm{~kg}$ of plutonium to reach criticality, which is larger than the total amount of plutonium contained in al1 of the sources and standards combined. 
HNF-2594, Rev. 0

Not only is this amount more plutonium than will be operationally stored, but

- The calculation assumes that the plutonium is pure ${ }^{239} \mathrm{Pu}$, while the plutonium in the test sources is weapons grade plutonium. The material in the non-PDP type sources, however, may be pure ${ }^{239} \mathrm{Pu}$.

- The calculation assumes no neutron absorbers. The sources and standards are encased in steel which will absorb neutrons.

- The calculation assumes the theoretical density of $\rho=10.11 \mathrm{~g} / \mathrm{cm}^{3}$ which is difficult to achieve in practice.

- The calculation assumes a perfectly spherical shape for the $\mathrm{PuO}_{2}$ while a series of cylindrical encapsulated sources would only approximate this shape.

These data apply to ${ }^{239} \mathrm{Pu}$ while some of the sources will be uranium, enriched in ${ }^{235} \mathrm{U}$. However, the ${ }^{239} \mathrm{Pu}$ is the limiting case even when compared to $100 \%{ }^{235} \mathrm{U}$ and thus this critical mass is the smallest critical mass of both elements. The geometry of the test containers is not relevant to this conclusion as long as the mass and spacing limits are adhered to. 


\section{HNF-2594, Rev. 0}

\subsection{TECHNICAL PEER REVIEW}

Document Reviewed:

CSER-98-002: Criticality Analysis for the Storage of Special Nuclear Material Sources and Standards in the WRAP Facility

Author:

Harvey Goldberg

Yes No N/A

冈[] []

Problem completely defined.

[४[] []

Necessary assumptions explicitly stated and supported.

[] [] $\mathbb{X}$

Computer codes and data files documented.

肉 []

Data checked for consistency with original source information as applicable.

[] []

Mathematical derivations checked including dimensional consistency of results.

$\mathbb{Q}[][]$

[] [] $\mathrm{M}$

[] [] $\mathrm{X}$

[] [] 边

W [] []

$\mathrm{X}[\mathrm{C}[\mathrm{]}$

[X] [] []

肉 [] []

[X] [] []

[] [] $\bigotimes$

[] []凶

[] [] $\mathrm{A}$

[] []

Models appropriate and used within range of validity or use outside range of established

validity justified.

Hand calculations checked for errors.

Code run streams correct and consistent with analysis documentation.

Code output consistent with input and with results reported in analysis documentation.

Acceptability limits on analytical results applicable and supported. Limits checked against sources.

Safety margins consistent with good engineering practices.

Conclusions consistent with analytical results and applicable limits.

Results and conclusions address all points required in the problem statement.

Have all reasonable accidents been considered?

Has low density water (steam) been evaluated as a moderator?

Is the fuel and other hardware composition correct?

Are the cases considered appropriately conservative?

Do the computer models adequately reflect the actual geometry? Have cross sectional cuts of the geometry been made and do they show the desired geometry?

$\mathbb{X}[][]$

Has the reviewer completed the Criticality Safety Course for Managers and Engineers?

Reviewed by: $\frac{\text { Wa. Date completed } 13 \text { Mav } 1998}{\text { David G. Ericksan }}$ Date

NOTE: Any hand calculations, notes, or summaries generated as part of this review should be signed, dated, and attached to this checklist. Materials should be labeled and recorded so that it is intelligible to a technically-qualified third party. 
HNF-2594

\subsection{REFERENCES}

ARHC0,1968, Criticality Handbook, ARH-600, R.D.Carter, G.R.Kiel, K.R.Ridgway, \& W.A. Blyckert, Atlantic Richfield Hanford Company, Richland, Washington, 28 August 1968. 


\section{DISTRIBUTION SHEET}

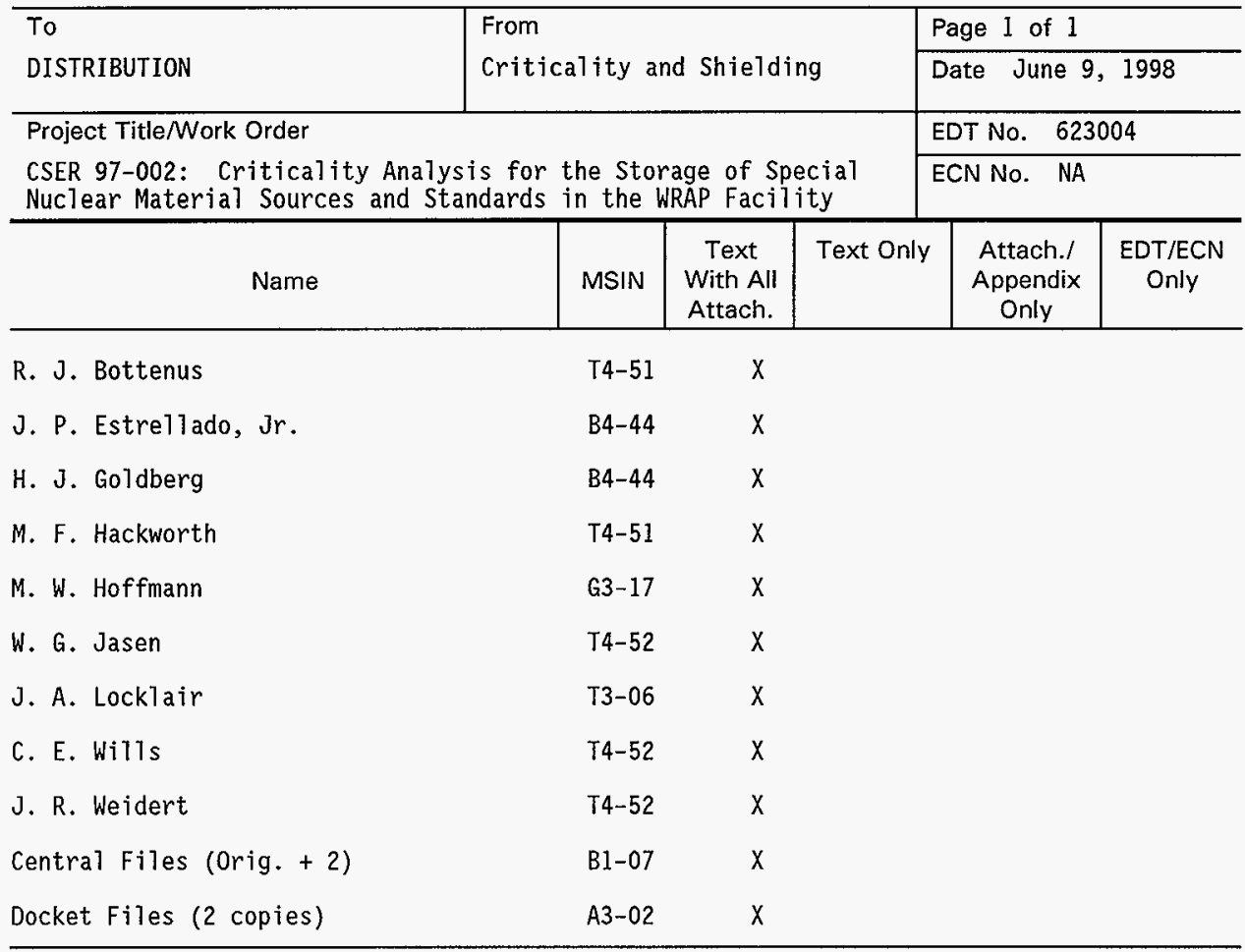

